OPEN ACCESS

Edited by:

Kum Fai Yuen,

Nanyang Technological University,

Singapore

Reviewed by:

Yusheng Zhou,

Nanyang Technological University,

Singapore

Ileana Espejel,

Universidad Autónoma de Baja

California, Mexico

*Correspondence:

Dan R. Reineman

dan.reineman@csuci.edu

Specialty section:

This article was submitted to

Marine Affairs and Policy,

a section of the journal

Frontiers in Marine Science

Received: 02 February 2021

Accepted: 01 March 2021

Published: 29 March 2021

Citation:

Reineman DR, Koenig $K$

Strong-Cvetich N and Kittinger JN

(2021) Conservation Opportunities

Arise From the Co-Occurrence

of Surfing and Key Biodiversity Areas.

Front. Mar. Sci. 8:663460.

doi: 10.3389/fmars.2021.663460

\section{Conservation Opportunities Arise From the Co-Occurrence of Surfing and Key Biodiversity Areas}

\author{
Dan R. Reineman ${ }^{1 *}$, Kellee Koenig ${ }^{2}$, Nik Strong-Cvetich ${ }^{3,4}$ and John N. Kittinger ${ }^{5,6}$ \\ ${ }^{1}$ Environmental Science and Resource Management Program, California State University Channel Islands, Camarillo, CA, \\ United States, ${ }^{2}$ The Betty and Gordon Moore Center for Science, Conservation International, Arlington, VA, United States, \\ ${ }^{3}$ Save The Waves Coalition, Santa Cruz, CA, United States, ${ }^{4}$ Middlebury Institute of International Studies at Monterey, \\ Monterey, CA, United States, ${ }^{5}$ Center for Oceans, Conservation International, Honolulu, HI, United States, ${ }^{6}$ Global Futures \\ Laboratory, School of Sustainability, Arizona State University, Tempe, AZ, United States
}

Conserving biodiversity and ecosystem services requires diverse models that empower communities to steward and benefit from resources. Here we investigate the potential of surfing resources, a new conservation asset class, and the surfing community, an underutilized conservation constituency, to conserve marine biodiversity. We conducted a spatial analysis of the overlap among Key Biodiversity Areas, Marine Protected Areas (MPAs), and 3,755 surf breaks globally. We find that $62.77 \%$ of surf breaks are not within MPAs and that $25.81 \%$ of all surf breaks are within $5 \mathrm{~km}$ of a Key Biodiversity Area, but are not within a MPA, suggesting that strategic conservation opportunities arise from the co-occurrence of surfing resources and biodiversity priorities. Establishing or extending protections to surfing ecosystems could increase protection for biodiversity at one-quarter of surf breaks. Sustainable management of these resources ensures their ability to provide for the character, economy, and development of coastal communities worldwide.

Keywords: biodiversity, conservation, marine protected areas, resource management, surf breaks, surfing resources

\section{INTRODUCTION}

Ocean ecosystems provide critical social, economic, and cultural life support systems for communities globally, yet are subject to an increasingly intense onslaught of anthropogenic threats that diminish these benefits. In response, governments, communities, and organizations have employed a range of approaches to better protect species, habitats, and ecosystem functions to mitigate human threats. Global targets have been established to drive governments toward agreedupon conservation goals, in order to protect a minimum percent of ecologically critical land and seascapes necessary to sustain global biodiversity and the services it provides to humanity (Hannah et al., 2020). Reaching global targets requires massive global investment to increase coverage of Marine Protected Areas (MPAs) and improve their implementation.

Historically, most ocean conservation efforts focus on specific resources, including targeted species or iconic ecosystems (e.g., fisheries or coral reefs). Here, we focus on surf breaks, an asset class of ocean resources that harbor underappreciated conservation and sustainable development 
opportunities. Waves are oceanographic phenomena that transmit energy across oceans at basin-wide scales (Garrison, 2001). Arriving at coastlines, waves break in patterns favorable for surfing - the practice of riding breaking waves-at typically nearshore, generally discrete locations called surf breaks (Butt et al., 2004; Scarfe et al., 2009). Surf breaks have natural and cultural endowments with significant value for stakeholders across economic (Nelsen et al., 2007; Lazarow et al., 2008; Buckley et al., 2014; Ponting and O’Brien, 2015; McGregor and Wills, 2016), cultural (Ford and Brown, 2005; Barbieri and Sotomayor, 2013; Mixon, 2014; Usher and Kerstetter, 2015), historical (Warshaw, 2010; Westwick and Neushul, 2013), and other dimensions (Taylor, 2007; Moore, 2011; Reineman and Ardoin, 2018) at local scales to global scales (see, e.g., Butt et al., 2004; Nelsen et al., 2007; Lazarow et al., 2008; Buckley et al., 2014).

Despite this significant value, surf breaks-and their surrounding ecosystems ("surfing resources"; Atkin et al., 2019) that shape them-are subject to diverse threats. These include physical impacts from global climate change and sea level rise (Hemer et al., 2013; Reineman et al., 2017), coastal modification and development (Corne, 2009; Scarfe et al., 2009), and coral reef decline (important ecosystems for surf breaks in the tropics; Hoegh-Guldberg et al., 2017). Additional factors limit people's ability to benefit from surfing resources, including coastal access disruption (Reineman et al., 2016; Reineman and Ardoin, 2018), insults to coastal water quality and associated health outcomes (Grant et al., 2001; Fewtrell and Kay, 2015), and sociocultural factors such as crowding and territoriality (Bandeira, 2014; Mixon, 2014; Usher and Kerstetter, 2015; Towner, 2016; Usher and Gómez, 2016). Recognition of these threats has increased in recent decades and responses have emerged at various scales, from formal institutional recognition of surfing resource management necessity at national scales (e.g., in New Zealand, Australia, and Peru), to civil society organizations proliferating and leading efforts at local to regional scales [e.g., efforts by Save The Waves Coalition (STW)], to site-specific efforts (e.g., listing of Surfrider Beach in Malibu, CA, United States on the United States National Register of Historic Places).

Surf conservation, the resources it seeks to sustain, and the wider ecosystems in which surfing resources are embedded have received less attention in the conservation movement relative to other cultural resources (e.g., shipwrecks) or biological resources that have long been the focus for marine conservation efforts (see, e.g., U.N. Sustainable Development Goal 14: Conserve and sustainably use the oceans, seas and marine resources for sustainable development). This is changing as communities, researchers, and practitioners increase understanding and visibility of the value of surf breaks for local and, particularly, developing economies (McGregor and Wills, 2016). At the Uluwatu surf area in Bali, Indonesia, for example-a priority region for coral reef and marine mammal conservation-a survey of surf tourists' expenditures estimated the total actual annual expenditure to be $\$ 35.3 \mathrm{M}$ USD per year. This major socioeconomic benefit was previously underrecognized and therefore not available for consideration in planning processes for coastal developments that would have affected wave quality and, by extension, surf ecotourism (Margules et al., 2014). Globally, surf tourism is valued at $\$ 31.5$ to $\$ 64.9$ B USD with participants willing to pay more for sustainable surf tourism opportunities (Mach and Ponting, 2021). Such benefits provide the mechanism to accelerate economic growth in communities surrounding surf breaks-an effect magnified in emerging economies (McGregor and Wills, 2016).

The co-location of surfing resources with other priority conservation targets thus represents a significant conservation opportunity. Here, we assess the conservation opportunities arising from the co-occurrence of surfing and biodiversity priority areas globally. Based on our analysis, we explore the potential impacts of joint conservation and sustainable development initiatives that will protect biodiversity and the important values and benefits that surfing resources provide to communities.

\section{MATERIALS AND METHODS}

We compiled and analyzed global databases of (1) surf break locations, (2) designated protected areas, (3) biodiversity conservation priority areas, and (4) national jurisdictional boundaries using ArcGIS for Desktop software [Environmental Systems Research Institute, Inc. (Esri), Redlands, CA United States]. The attributes of each dataset, including qualifications on data quality and technical information pertaining to data processing are included in the Supplemental Online Materials. We briefly summarize the data used here:

(1) Surf breaks: We draw on a proprietary dataset of surf break locations provided by Surfline/Wavetrak, Inc. (Huntington Beach, CA United States; "Surfline"), generally considered to set the industry standard. After excluding artificial (i.e., human-made) and freshwater (e.g., lake-based) surf breaks, this dataset contains 3,755 individual surf break locations.

(2) Protected Areas: Location and extent of marine and coastal protected areas were obtained from the World Database of Protected Areas (WDPA), downloaded in May 2019 via the online portal ${ }^{1}$. Coastal protected areas were included because of their potential impact on surfing resources.

(3) Biodiversity conservation priority areas: Global Key Biodiversity Areas (KBAs), obtained in March 2019 from the KBA Partnership ${ }^{2}$. KBAs are site-level priorities for biodiversity conservation based on standardized criteria with delineated boundaries that are actually or potentially manageable as a unit (KBA Standards and Appeals Committee, 2019). ${ }^{3}$

(4) National boundaries and jurisdictions were derived from datasets published by the Flanders Marine Institute,

\footnotetext{
${ }^{1}$ https://www.protectedplanet.net/

${ }^{2}$ http://www.keybiodiversityareas.org/home

${ }^{3}$ Other sources exist for spatial biodiversity data (see, e.g., Selig et al., 2014) but due to mismatches in scale and regional foci, these were eschewed in favor of the KBA dataset.
} 
downloaded May 2019 at http://www.marineregions.org. The "Union of the Esri Country shapefile and the Exclusive Economic Zones (version 2)" was updated using their Exclusive Economic Zones v10 dataset.

These data were prepared, integrated, and analyzed in ArcMap to identify intersections of points and areas. Geodesic buffers ( 1 and $5 \mathrm{~km}$ ) were drawn around each surf break because, while each surf break is designated in the dataset with a single, one-dimensional point, actual surf breaks extend over tens to hundreds of meters or more (Butt et al., 2004). The $5 \mathrm{~km}$ buffer areas are inclusive of intersections lying within the $1 \mathrm{~km}$ buffer areas.

\section{RESULTS}

Surf breaks are globally distributed (3,755 distinct surf breaks among 93 countries); representation by country varies in the dataset, with 50 countries containing 10 or more surf breaks accounting for $94.57 \%$ of surf breaks and 6 countries accounting for $59.15 \%$ of the global total. Many surf breaks are already situated within-and more are situated near-existing protected areas, but roughly three-fifths of all surf breaks $(62.77 \%)$ are not within protected areas. When a surf break's point-location is expanded to include the surrounding area (i.e., its surfing ecosystem: Arroyo et al., 2019), the proportions are much higher: $60.67 \%$ lie within $1 \mathrm{~km}$ and $80.77 \%$ lie within $5 \mathrm{~km}$ of existing protected areas. Likewise, the overall proportion of surf breaks situated within KBAs is $14.81 \%$, but increases as the buffer area is expanded: $30.95 \%$ of surf breaks lie within $1 \mathrm{~km}$ of a KBA and 46.44\% lie within $5 \mathrm{~km}$ see Table $\mathbf{1}$.

The potential permutations of surf breaks lying in/out of protected area versus in/near/out of a KBA, suggests a $2 \times 2$ matrix and yields a typology with four types of surf break: those not within a KBA and not within a protected area (Type I; $56.56 \%$ ); those within a KBA and within a protected area (Type II; $8.60 \%$ ); those not within a KBA but within a protected area (Type III; 28.63\%); and those within a KBA but not within a protected area (Type IV; 6.21\%). Table 2 displays this matrix. Using buffer areas to incorporate the surfing ecosystem has strong implications for the resulting permutations by changing the likelihood of intercept with a key biodiversity area, as shown within each cell of the Table 2 matrix on the 1 and $5 \mathrm{~km}$ data lines. For example, of Type IV surf breaks: $6.21 \%$ are in a KBA, $15.45 \%$ are within $1 \mathrm{~km}$ of a KBA, and $25.81 \%$ are within $5 \mathrm{~km}$ of a KBA. Figure 1 displays the locations of surf breaks worldwide and highlights the Type IV breaks. Table 2 additionally displays the number of countries in which greater than $50 \%$ of surf breaks match each type (see parenthetical numbers within matrix cells).

\section{DISCUSSION}

Surf breaks-and their surrounding areas and ecosystems that comprise the surfing resource (Atkin et al., 2019)—represent a new asset class in conservation, constituting a valuable physical and sociocultural resource that is globally distributed. These
TABLE 1 | Summary location data.

\begin{tabular}{|c|c|c|}
\hline & Subtotal & Proportion of total surf breaks \\
\hline Total surf breaks & 3755 & \\
\hline \multicolumn{3}{|c|}{ Total countries with surf breaks represented $=93$} \\
\hline $\begin{array}{l}50 \text { Countries with } 10 \text { or more } \\
\text { surf breaks }\end{array}$ & 3551 & $94.57 \%$ \\
\hline $\begin{array}{l}\text { Surf breaks within } \\
\text { United States, Australia, Brazil, } \\
\text { Mexico, Japan, and France }\end{array}$ & 2221 & $59.15 \%$ \\
\hline \multicolumn{3}{|l|}{ Surf breaks located:* } \\
\hline Within a protected area (PA) & 1398 & $37.23 \%$ \\
\hline $1 \mathrm{~km}$ of PA & 2278 & $60.67 \%$ \\
\hline $5 \mathrm{~km}$ of PA & 3033 & $80.77 \%$ \\
\hline $\begin{array}{l}\text { Within a key biodiversity area } \\
\text { (KBA) }\end{array}$ & 556 & $14.81 \%$ \\
\hline $1 \mathrm{~km}$ of $\mathrm{KBA}$ & 1162 & $30.95 \%$ \\
\hline $5 \mathrm{~km}$ of $\mathrm{KBA}$ & 1744 & $46.44 \%$ \\
\hline
\end{tabular}

Table includes surf break co-location with protected areas and key biodiversity areas. *l.e., The surf break's point location or else a 1 or $5 \mathrm{~km}$ buffer around its point location break overlaps a protected area or KBA.

\begin{tabular}{|c|c|c|c|}
\hline & & \multicolumn{2}{|c|}{ Protected area } \\
\hline & & Not within & Within \\
\hline \multirow{8}{*}{ 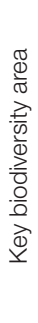 } & \multirow{4}{*}{ 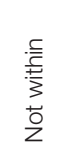 } & Type I & Type III \\
\hline & & $2124 ; 56.56 \%(61)$ & $1075 ; 28.63 \%(5)$ \\
\hline & & $1 \mathrm{~km}-1777 ; 47.32 \%(49)$ & $1 \mathrm{~km}-816 ; 21.73 \%(3)$ \\
\hline & & 5 km - 1388; 36.96\% (32) & $5 \mathrm{~km}-623 ; 16.59 \%(2)$ \\
\hline & \multirow{4}{*}{ 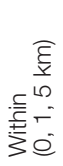 } & Type IV & Type II \\
\hline & & $233 ; 6.21 \%(4)$ & 323; 8.60\% (5) \\
\hline & & $1 \mathrm{~km}-580 ; 15.45 \%(9)$ & $1 \mathrm{~km}-582 ; 15.50 \%(5)$ \\
\hline & & 5 km - 969; 25.81\% (22) & $5 \mathrm{~km}-775 ; 20.64 \%(7)$ \\
\hline
\end{tabular}

This $2 \times 2$ matrix displays summary data on the number of surf breaks and countries matching the criteria for each Type, depending whether an individual surf break is located out of or else within 0, 1, or $5 \mathrm{~km}$ of a Protected Area or Key Biodiversity Area. Each cell contains, for each intercept radius, the (global) total count of Type, the Type's proportion of global total, and, in parentheses, the count of countries in which greater than 50\% of surf breaks match the Type.

resources are critically important to a large constituency of ocean users-surfers-and an associated, growing industry. There are over 34 million surfers worldwide, while the surf industry is valued at over 11 billion USD. Ecotourism is growing at 44\% globally (compared to mass tourism at $4 \%$ ) and ecotourists are willing to pay up to $25 \%$ more for experiences that directly benefit communities. Surfers are intimately knowledgeable about coastal environments and deeply connected with coastal places; displacement of this constituency through loss of surf breaks has negative consequences (Reineman, 2016; Reineman and Ardoin, 2018). In contrast, proactive management and careful protection of surfing resources could protect and sustain their significant economic and development benefits (Lazarow et al., 2008; McGregor and Wills, 2016). Our findings show that nearly two-thirds $(62.77 \%)$ of surf breaks are not currently located within protected areas (Table 1), presenting an opportunity to 


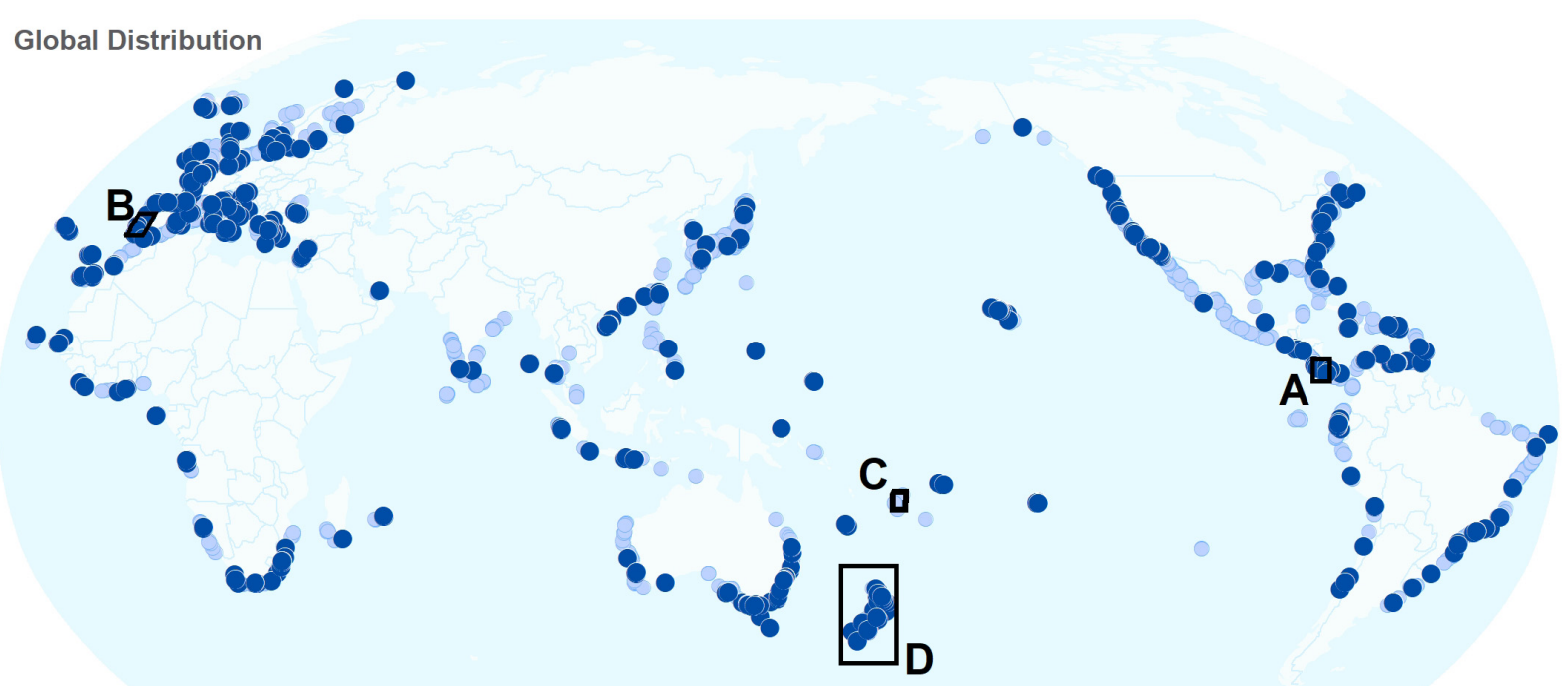

Surf break in or near a KBA and not within a protected area (Type IV)

- All other surf breaks

Inset Maps Illustrating Surf Break Types
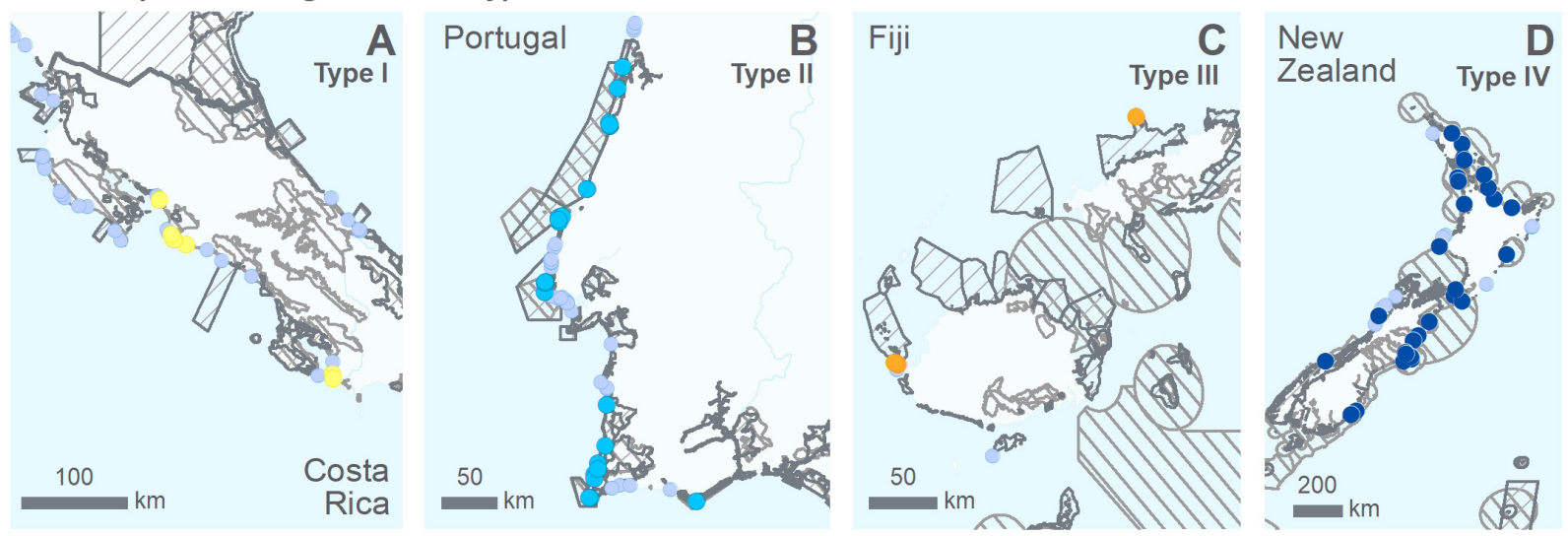

Surf breaks neither in or near KBAs nor within protected areas (Type I)

- Surf breaks both in or near KBAs and within protected areas (Type II)

- Surf breaks not in or near KBAs, but within protected areas (Type III)

- Surf breaks in or near KBAs, but not within protected areas (Type IV)

- All other surf breaks

FIGURE 1 | Global distribution of surf breaks illustrating co-beneficial conservation opportunities, where protection of currently unprotected marine areas could benefit surfing resources and biodiversity. Further analysis of the spatial occurrence of surfing resources, biodiversity areas, and protected areas yields a typology of four Types of surf breaks: (I) not within either a KBA or protected area, (II) within both a KBA and a protected area, (III) not within a KBA but within a protected area, and (IV) within a KBA but not within a protected area. The global map highlights Type IV. Inset maps illustrate four example countries whose surf breaks currently comprise a majority of each type: (A) Costa Rica (Type I), (B) Portugal (Type II), (C) Fiji (Type III), and (D) New Zealand (Type IV). Any surf break's current type could change based on a modification of its country's protected area regime or subsequent change in biodiversity status (or wholesale loss of the surf break itself).

expand conservation programs to protect these resources and associated ecosystems.

Indeed, protection of surfing resources is likely best achieved through full consideration of their surrounding systems since the value of the surf break itself is predicated on a suite of important and interacting factors, both physical and biological, which combine to shape the quality of a surf break (Arroyo et al., 2019; Atkin et al., 2019). These factors rely on phenomena and 
processes whose spatial scales certainly extend beyond the nonspatial "point" locations used in our analyses to represent surf break location and, in some cases, beyond the $5 \mathrm{~km}$ buffer area we use (Butt et al., 2004). The surfing experience is impacted by pressures that also threaten biodiversity, including pollution and water quality, destruction or modification of habitat, and rising sea levels. These threats likewise operate at scales beyond the point location of a surf break. A proportion, $6.21 \%$ of surf breaks not currently within protected areas are within KBAs; this percentage climbs to $25.81 \%$ when the surf break's surrounding area is expanded by a $5 \mathrm{~km}$ radius (Type IV; Table 2). In other words, many surf breaks are adjacent to or within the vicinity of KBAs.

This co-occurrence presents opportunities for co-benefits to both biodiversity conservation and the sustainable development potential of surfing resource protection. In the roughly $20 \%$ of surf breaks located within a protected area and also within $5 \mathrm{~km}$ of a KBA (Type II; Table 2), the existing protections may not necessarily extend to conserve surfing resources (i.e., the restrictions within a given protected area may focus specifically on non-surfing-related resources, such as fishery "no take" areas). Therefore, even with protected areas in place, some related socioeconomic and cultural values of surfing resources are probably not protected. Extending protections to surfing resources in these existing protected areas could have additional ecosystem and biodiversity co-benefits, including advancing global marine conservation priorities (e.g., IUCN's World Conservation Congress 2016 Resolution 50 for 30\% global marine protected area coverage by 2030).

The geographic scale and distribution of protection for surfing resources, like many marine conservation targets, is itself unevenly distributed. This is reflected in our analyses, which show "scale" differences: as surf breaks are expanded to include the surrounding areas important for surfing resources, the conservation co-benefit potential increases as the surfing area protected increases (Type II and Type IV; Table 2). "Distributional differences" are highlighted by the disproportional allocations of surf breaks among countries globally (Table 1). Surf breaks are not evenly distributed: countries with more coastline have more potential locations for surf breaks, however, there is also bias in the surf break dataset (see explanation in SOM). Still, our analyses suggest that individual countries have widely varying potential for biodiversity co-benefits from surf break conservation. This is illustrated by the examples of Costa Rica, Portugal, Fiji, and New Zealand (see Figure 1 insets).

Costa Rica has a high proportion of Type I surf breaks located outside of both protected areas and KBAs (Figure 1A). This reflects a pattern in many countries, where an underinvestment in MPAs has left a majority of nearshore areas unprotected, including in areas where there are substantial surf resources. In countries like Costa Rica, there is a high potential to protect coastal areas where surf breaks are an important resource. Though this potential does not include designated biodiversity areas in Costa Rica, ecosystem protections could expand to include conservation measures for coastal fisheries. Given the national significance of coastal, and specifically surf-related tourism in Costa Rica (Tantamjarik, 2004), creation and extension of protected areas to include surfing resources would be of substantial benefit to ensuring biodiversity and the sustainable tourism and development opportunities for surf breaks.

Portugal has a high proportion of Type II surf breaks located within both protected areas and KBAs (Figure 1B). There is potential to revisit protected area designations there to determine whether they extend to recreational resources generally and to surfing resources specifically. In countries like Portugal, MPAs generally focus on fisheries such that "recreational resources" regulated within MPAs are extractive in nature. There is recognition of surfing's significance in Portugal where, among other things, a World Surfing Reserve has been designated at Ericeira by the STW. ${ }^{5}$ This NGO-provided designation does not compel any enforceable governance measures within the reserve, but does provide surfing conservation advocates a powerful advocacy tool there and elsewhere within Portugal's well-developed MPA system.

Fiji has a high proportion of Type III surf breaks located within a protected area but not within a KBA (Figure 1C). Expansion of protected area restrictions to include the suite of resources and threat reduction measures that support surf break quality would have benefits for both surfing resources and their surrounding ecosystems. In Fiji, these are generally coral reefs, which are significant for both inshore fisheries and nonsurfing ecotourism, like SCUBA diving (Teh et al., 2009). While there are not immediate benefits to a designated KBA, including surfing resources within Fiji's existing protected areas could yield additional ecosystem benefits.

New Zealand has a high proportion of Type IV surf breaks located within a KBA but not within a protected area (Figure 1D) - and illustrates several caveats with our analyses and spatial protections for surfing resources more generally. Despite the lack of protected areas encompassing surf breaks in New Zealand, protections for surf breaks do exist via the national Coastal Policy Statement of 2010, which identifies 17 Surf Breaks of National Significance ${ }^{6}$ and stipulates that impacts to these breaks be avoided. Recently published guidance provides New Zealand managers, surfers, and other stakeholders with clear processes for considering and avoiding impacts to that nation's surf breaks (Atkin et al., 2019). While these protections include some aspects of marine ecosystems, such as their physical structure, they do not necessarily, explicitly ensure protection of biodiversity as compared to comprehensive protected areas.

As these countries illustrate, while protected areas targeting biodiversity and ecosystems proliferate globally, there are very few examples of protected areas explicitly designed for surf break conservation, despite their value as natural,

\footnotetext{
${ }^{4}$ See http://mpas-portugal.org/(last accessed 24 March 2020).

${ }^{5}$ See https://www.savethewaves.org/programs/world-surfing-reserves/reserves/ portugal/(last accessed 24 March 2020).

${ }^{6}$ See Policy 16, via https:/www.doc.govt.nz/about-us/science-publications/ conservation-publications/marine-and-coastal/new-zealand-coastal-policystatement/new-zealand-coastal-policy-statement-2010/(last accessed 24 March 2020).
} 
recreational, and cultural endowments. By contrast, sitebased protections for other non-extractive marine activities are common (e.g., shipwrecks, SCUBA, or ecotourism sites). Additionally, terrestrial systems host many examples of naturebased conservation designations for recreational values (e.g., National Parks, as established by countries worldwide). These countries also illustrate a key limitation of these analyses, which, as a global-level review, do not delve into the variety and complexity of marine resource management strategies on a country-by-country basis. This is likewise underscored by the challenge of identifying tractable, comprehensive, globalscale datasets of MPAs, biodiversity, and surfing resources. Our analyses are thus constrained by the limitations of these datasets that, while analytically tractable and global in scale, each have benefits and drawbacks in terms of the data included or excluded. For example, the WDPA includes areas with widely varying levels of protection-these may or may not be relevant to surfing resources depending on their specific nature and scale. However, as a brief report of a novel, global analysis, we acknowledge these limitations and encourage other researchers to tackle the fine-resolution, country-scale and smaller, analyses of more comprehensive local datasets.

As the world's marine ecosystems continue to be threatened by overfishing, pollution, poorly planned development, and changing climate, global conservation efforts will benefit from diverse participants and strategies. Considerations for surfing resource management are the subject of increasing attention, from human-impact indicator development (Arroyo et al., 2020) to practical applications of various site-management techniques (Blum and Orbach, 2021): these studies underscore local, site-specific complexities in planning and implementation. Combining surfing resource conservation with biodiversity conservation can potentially protect millions of hectares of habitat that might otherwise be overlooked. There are examples where this has occurred indirectly (as when surf breaks lie within MPAs targeting other resources) or by other means (such as non-governmental designations of surf reserves), but a systematic approach to identify and act upon opportunities to achieve co-beneficial impacts to surfing and biodiversity resources can yield more positive impacts. These

\section{REFERENCES}

Arroyo, M., Levine, A., Brenner, L., Seingier, G., Leyva, C., and Espejel, I. (2020). Indicators to measure pressure, state, impact and responses of surf breaks: the case of Bahía de Todos Santos World Surfing Reserve. Ocean Coast. Manag. 194:105252. doi: 10.1016/j.ocecoaman.2020.105252

Arroyo, M., Levine, A., and Espejel, I. (2019). A transdisciplinary framework proposal for surf break conservation and management: Bahía de Todos Santos World Surfing Reserve. Ocean Coast. Manag. 168, 197-211. doi: 10.1016/j. ocecoaman.2018.10.022

Atkin, E., Bryan, K., Hume, T., Mead, S. T., and Waiti, J. (2019). Management Guidelines for Surfing Resources. Raglan: Aotearoa New Zealand Association for Surfing Research.

Bandeira, M. M. 2014. Territorial disputes, identity conflicts, and violence in surfing. Motriz: Revista de Educação Física 20, 16-25.

Barbieri, C., and Sotomayor, S. (2013). Surf travel behavior and destination preferences: an application of the serious leisure inventory and could accrue to local communities and the surf ecotourism sector, but only if the underlying resources-surf breaks-are sustainably managed. Continued identification, prioritization, and protection surf breaks is thus an opportunity to both ensure sustainable management and, as we show, to realize an as-yet-untapped avenue for biodiversity conservation. We encourage further research into these opportunities-especially careful, local-to-regional analyses parsing unique, site-specific characteristics of surfing resources, biodiversity conservation needs, and protected area status and which could guide targeted conservation efforts.

\section{DATA AVAILABILITY STATEMENT}

The original contributions presented in the study are included in the article/Supplementary Material, further inquiries can be directed to the corresponding author/s.

\section{AUTHOR CONTRIBUTIONS}

DR led preparation of manuscript and supervision of analyses. JK and NS-C brainstormed initial project, contributed to writing, and assisted with supervision of analyses. KK conducted analyses and contributed to writing. All authors contributed to the article and approved the submitted version.

\section{ACKNOWLEDGMENTS}

The authors are grateful to Surfline/Wavetraks, Inc., for making their global database of surf break locations available to our team.

\section{SUPPLEMENTARY MATERIAL}

The Supplementary Material for this article can be found online at: https://www.frontiersin.org/articles/10.3389/fmars. 2021.663460/full\#supplementary-material

measure. Tour. Manag. 35, 111-121. doi: 10.1016/j.tourman.2012. 06.005

Blum, M. L., and Orbach, M. K. (2021). First steps at first point: protecting California surf breaks and the Malibu historic district. Coast. Manag. 49, 201-214. doi: 10.1080/08920753.2021.1875392

Buckley, R., Shakeela, A., and Guitart, D. (2014). Adventure tourism and local livelihoods. Ann. Tour. Res. 48, 269-272. doi: 10.1016/j.annals.2014. 06.006

Butt, T., Russell, P., and Grigg, R. (2004). Surf Science: An Introduction to Waves for Surfing. 2nd Edn. Honolulu: University of Hawaii Press.

Corne, N. P. (2009). The implications of coastal protection and development on surfing. J. Coast. Res. 252, 427-434. doi: 10.2112/07-0932.1

Fewtrell, L., and Kay, D. (2015). Recreational water and infection: a review of recent findings. Curr. Environ. Health Rep. 2, 85-94. doi: 10.1007/s40572-0140036-6

Ford, N., and Brown, D. (2005). Surfing and Social Theory: Experience, Embodiment and Narrative of the Dream Glide. London: Routledge, 1-204. 
Garrison, T. (2001). Oceanography: An invitation to marine science, 3rd Edn. Pacific Grove, CA: Brooks/Cole.

Grant, S. B., Sanders, B. F., Boehm, A. B., Redman, J. A., Kim, J. H., Mrše, R. D., et al. (2001). Generation of enterococci bacteria in a coastal saltwater marsh and its impact on surf zone water quality. Environ. Sci. Technol. 35, 2407-2416. doi: $10.1021 /$ es 0018163

Hannah, L., Roehrdanz, P. R., Marquet, P. A., Enquist, B. J., Midgley, G., Foden, W., et al. (2020). $30 \%$ land conservation and climate action reduces tropical extinction risk by more than 50\%. Ecography 43, 943-953. doi: 10.1111/ecog. 05166

Hemer, M. A., Fan, Y., Mori, N., Semedo, A., and Wang, X. L. (2013). Projected changes in wave climate from a multi-model ensemble. Nat. Clim. Chang. 3 , 471-476. doi: 10.1038/nclimate1791

Hoegh-Guldberg, O., Poloczanska, E. S., Skirving, W., and Dove, S. (2017). Coral reef ecosystems under climate change and ocean acidification. Front. Mar. Sci. 4:158. doi: $10.3389 /$ fmars. 2017.00158

KBA Standards and Appeals Committee (2019). Guidelines for Using a Global Standard for the Identification of Key Biodiversity Areas: version 1.0. Gland: IUCN, International Union for Conservation of Nature.

Lazarow, N., Miller, M. L., and Blackwell, B. (2008). The value of recreational surfing to society. Tour. Mar. Environ. 5, 145-158. doi: 10.3727/ 154427308787716749

Mach, L., and Ponting, J. (2021). Establishing a pre-COVID-19 baseline for surf tourism: trip expenditure and attitudes, behaviors and willingness to pay for sustainability. Ann. Tour. Res. Empir. Insights 2:100011. doi: 10.1016/j.annale. 2021.100011

Margules, T., Ponting, J., Lovett, E., Mustika, P., and Pardee Wright, J. (2014), Assessing Direct Expenditure Associated with Ecosystem Services in the Local Economy of Uluwatu, Bali, Indonesia. Arlington County, VA: Conservation International and the Center for Surf Research.

McGregor, T., and Wills, S. (2016). Natural Assets: Surfing a Wave of Economic Growth. OxCarre Working Papers 170. Oxford: University of Oxford.

Mixon, F. G. (2014). Bad vibrations: new evidence on commons quality and localism at California's surf breaks. Int. Rev. Econ. 61, 379-397. doi: 10.1007/ s12232-014-0205-9

Moore, C. (2011). Spiritual Experiences and Environmentalism of Recreational Users in the Marine Environment: New Zealand Surfers and Scuba Divers. Master's thesis, Lincoln University, Christchurch.

Nelsen, C., Pendleton, L., and Vaughn, R. (2007). A socioeconomic study of surfers at Trestles Beach. Shore Beach 75, 32-37.

Ponting, J., and O’Brien, D. (2015). Regulating "Nirvana”: sustainable surf tourism in a climate of increasing regulation. Sport Manag. Rev. 18, 99-110. doi: 10. 1016/j.smr.2014.07.004

Reineman, D. R. (2016). The utility of surfers' wave knowledge for coastal management. Mar. Policy 67, 139-147. doi: 10.1016/j.marpol.2016. 01.023
Reineman, D. R., and Ardoin, N. M. (2018). Sustainable tourism and the management of nearshore coastal places: place attachment and disruption to surf-spots. J. Sustain. Tour. 26, 325-340. doi: 10.1080/09669582.2017.1352590

Reineman, D. R., Thomas, L. N., and Caldwell, M. R. (2017). Using local knowledge to project sea level rise impacts on wave resources in California. Ocean Coast. Manag. 138, 181-191. doi: 10.1016/j.ocecoaman.2017.01.020

Reineman, D. R., Wedding, L. M., Hartge, E. H., Mcenery, W., and Reiblich, J. (2016). Coastal access equity and the implementation of the California Coastal Act. Stanf. Environ. Law J. 36:89.

Scarfe, B. E., Healy, T. R., Rennie, H. G., and Mead, S. T. (2009). Sustainable management of surfing breaks: case studies and recommendations. J. Coast. Res. 253, 684-703. doi: 10.2112/08-0999.1

Selig, E. R., Turner, W. R., Troeng, S., Wallace, B. P., Halpern, B. S., Kaschner, K., et al. (2014). Global priorities for marine biodiversity conservation. PLoS One 9:e82898. doi: 10.1371/journal.pone.0082898

Tantamjarik, P. A. (2004). Sustainability Issues Facing the Costa Rica Surf Tourism Industry. Master's thesis, University of Hawai'i, Honolulu.

Taylor, B. (2007). Surfing into spirituality and a new, aquatic nature religion. J. Am Acad. Relig. 75, 923-951. doi: 10.1093/jaarel/lfm067

Teh, L. C. L., Teh, L. S. L., Starkhouse, B., and Sumaila, U. R. (2009). An overview of socio-economic and ecological perspectives of Fiji's inshore reef fisheries. Mar. Policy 33, 807-817. doi: 10.1016/j.marpol.2009.03.001

Towner, N. (2016). How to manage the perfect wave: surfing tourism management in the Mentawai Islands, Indonesia. Ocean Coast. Manag. 119, 217-226. doi: 10.1016/j.ocecoaman.2015.10.016

Usher, L. E., and Gómez, E. (2016). Surf localism in Costa Rica: exploring territoriality among Costa Rican and foreign resident surfers. J. Sport Tour. 20, 195-216. doi: 10.1080/14775085.2016.1164068

Usher, L. E., and Kerstetter, D. (2015). Re-defining localism: an ethnography of human territoriality in the surf. Int. J. Tour. Anthropol. 4:286. doi: 10.1504/ijta. 2015.071930

Warshaw, M. (2010). The History of Surfing. San Francisco, CA: Chronicle Books.

Westwick, P., and Neushul, P. (2013). The World in the Curl: An Unconventional History of Surfing. New York, NY: Crown Publishers.

Conflict of Interest: The authors declare that the research was conducted in the absence of any commercial or financial relationships that could be construed as a potential conflict of interest.

Copyright () 2021 Reineman, Koenig, Strong-Cvetich and Kittinger. This is an openaccess article distributed under the terms of the Creative Commons Attribution License (CC BY). The use, distribution or reproduction in other forums is permitted, provided the original author(s) and the copyright owner(s) are credited and that the original publication in this journal is cited, in accordance with accepted academic practice. No use, distribution or reproduction is permitted which does not comply with these terms. 